\title{
Value of clinical, laboratory parameters and analysis of retinal vascularization in pediatric patients with portal hypertension
}

\author{
Mariana Batista GONÇALVES ${ }^{1}$, Bruno de Queiroz ALVES ${ }^{1}$, Bruna Ferraço MARIANELLI', \\ Murilo Ubukata POLIZELLI' ${ }^{1}$, Ramiro Anthero de AZEVEDO ${ }^{2,3}$ and Nilva Simeren Bueno de MORAES ${ }^{1}$
}

Received: 29 August 2019 Accepted: 27 April 2020

ABSTRACT - Background - Portal hypertension is one of the complications of cirrhosis and is associated with numerous systemic manifestations, including renal, brain, pulmonary, cardiac and vascular changes. In routine ophthalmological examinations performed at our service, we observed that some children diagnosed with portal hypertension had increased retinal vascular tortuosity. Objective - 1 . To evaluate the presence of retinal vascular abnormalities (vascular tortuosity) in children diagnosed with portal hypertension; 2 . To investigate the association between retinal vascular tortuosity and the presence of gastroesophageal varices in these children; 3 . To evaluate the use of clinical and laboratory parameters to predict the presence of gastroesophageal varices in children with portal hypertension. Methods - This was a cross-sectional and observational study that included patients aged $<18$ years with a diagnosis of portal hypertension. The participants included were submitted to dilated fundus examination and fundus photography with Visucam (Carl Zeiss Meditec AG) device. Besides, clinical and laboratorial data were collected from the patients' medical records. Results - A total of 72 patients were included in this study, and $36 \%$ of them had an increase in retinal vascular tortuosity. Platelet count $(P=0.001)$, bilirubin dosage $(P=0.013)$ and aspartate transaminase dosage (AST) $(P=0.042)$ were associated with the presence of gastroesophageal varices in digestive endoscopy. There was no association between retinal vascular tortuosity and the presence of gastroesophageal varices $(P=0.498)$. Conclusion - The results of this study suggest that platelet count, bilirubin dosage, and aspartate transaminase dosage were associated with the presence of gastroesophageal varices in digestive endoscopy. Regarding the retinal findings, we found that there was an increase in retinal vascular tortuosity in $36 \%$ of pediatric patients, but no association was found with the presence of gastroesophageal varices.

HEADINGS - Portal hypertension. Retinal vessels. Esophageal and gastric varices. Endoscopy. Retinal diseases.

\section{INTRODUCTION}

Portal hypertension $(\mathrm{PH})$ is one of the complications of cirrhosis and is associated with numerous systemic manifestations, including renal, brain, pulmonary, cardiac and vascular changes ${ }^{(1-4)}$. Among the ophthalmological findings described in this condition, we can mention xerophthalmia, keratoconjunctivitis sicca, night blindness, as well as the presence of cotton wool spots and hemorrhages in the retina ${ }^{(5)}$. In routine ophthalmological examinations performed at our service, we observed that some children diagnosed with portal hypertension had increased retinal vascular tortuosity.

In cirrhotic patients, the presence of gastroesophageal varices $(\mathrm{GEV})$ indicates a severe degree of $\mathrm{PH}^{(6)}$. Esophageal varices occur in $50 \%$ of cirrhotic adult patients at diagnosis and rupture of these vascular abnormalities occurs in approximately $25 \%$ to $30 \%$ of cases. In children, the total risk of bleeding from esophageal varices is estimated at $50 \%$, but this percentage may be higher depending on the underlying liver pathology $y^{(7)}$.

Many studies have been conducted to identify noninvasive clinical and laboratory methods that may predict the presence of GEV in patients with portal hypertension. Preliminary data sug- gest that the following data may be useful in identifying adult and pediatric patients who are at increased risk of developing varicose veins: 1) Platelet count; 2) Dosage of serum albumin; 3) Presence of splenomegaly; 4) Z score of spleen size; 5) Ratio between platelet count and spleen size; 6) Mathematical model: "Clinical Prediction Rule", calculated from platelet count, $\mathrm{Z}$ score of the spleen and albumin dosage ${ }^{(8)}$.

The objectives of this study were: 1) To evaluate the presence of retinal vascular abnormalities (vascular tortuosity) in children diagnosed with $\mathrm{PH}$; 2) To investigate the association between retinal vascular tortuosity and the presence of GEV in these children; 3) To evaluate the use of clinical and laboratory parameters to predict the presence of GEV in children with $\mathrm{PH}$.

\section{METHODS}

This was a cross-sectional and observational study carried out in the Departments of Ophthalmology and Hepatology of the Federal University of São Paulo (UNIFESP). The study was conducted after receiving approval from our Research Ethics Committee (number 82307718.9.0000.5505).

Declared conflict of interest of all authors: none

Disclosure of funding: no funding received

${ }^{1}$ Universidade Federal de São Paulo, Departamento de Oftalmologia e Ciências Visuais, Divisão de Retina e Vítreo, São Paulo, SP, Brasil. ${ }^{2}$ Universidade Federal de São Paulo, Divisão de Cirurgia Pediátrica, São Paulo, SP, Brasil. ${ }^{3}$ Universidade Federal de São Paulo, Divisão de Gastroenterologia Pediátrica, São Paulo, SP, Brasil.

Corresponding author: Murilo Ubukata Polizelli, MD. E-mail: murilopolizelli@gmail.com 
Patients who met the following criteria were included in this study: 1) Age <18 years; 2) Regular follow-up at the Hepatology Clinic; 3) Diagnosis of portal hypertension, defined as the presence of varices at endoscopy and/or other abdominal portosystemic collaterals, splenomegaly and ascites using doppler ultrasound and computed tomography ${ }^{(9)}$; 4) Signature of the informed consent form by the participant's legal representative. The exclusion criteria were: 1) Records with incomplete data; 2) Impossibility of signing the informed consent form.

The patients included in the study were submitted to dilated fundus examination and fundus photography with Visucam (Carl Zeiss Meditec AG) device. Retinal vessel tortuosity was evaluated simultaneously in both eyes and reported as the average evaluation of the right and the left eyes. In addition, the following data were collected from the patients' medical records: age, sex, main liver disease, renal function (urea and creatinine), liver function (gamma globulin GT, alkaline phosphatase, transaminases), electrolytes (sodium and potassium), platelet count, information on the presence or absence of splenomegaly, ascites and GEV on endoscopy.

Continuous variables were given as mean \pm standard deviation and categorical variables as frequencies. Categorical variables were compared by Fisher's exact test. Continuous variables were compared using the Mann-Whitney U test. Values of $P<0.05$ were considered statistically significant.

\section{RESULTS}

A total of 72 patients were included in this study. The mean age was 7.1 years $( \pm 5.2$ years $)$. Regarding the gender, $59.7 \%(n=43)$ were female and $40.3 \%(n=29)$ were male (TABLE 1$)$.

TABLE 1. Demographic profile of the 72 patients included in the study.

\begin{tabular}{lc}
\hline Variable & \\
\hline Female. N (\%) & $43 / 72(59.7 \%)$ \\
Age (years) & \\
Mean \pm SD & $7.1 \pm 5.2$ \\
Median (Min-Max) & 7.0 (4 days -16 years $)$ \\
\hline
\end{tabular}

Considering portal hypertension-related liver disease, $35 \%$ of study participants had biliary atresia. Others causes of PH included portal vein thrombosis, Alagille's syndrome, familial intrahepatic cholestasis, and autoimmune hepatitis (TABLE 2).

TABLE 2. Distribution of patients with portal hypertension according to the underlying liver disease.

\begin{tabular}{lc}
\hline Portal hypertension-related liver disease & \\
\hline Biliary atresia & $35 \%$ \\
Portal vein thrombosis & $15 \%$ \\
Alagille's syndrome & $8 \%$ \\
Progressive Familial Intrahepatic Cholestasis (PFIC) & $5 \%$ \\
Autoimmune hepatites & $4 \%$ \\
Others & $33 \%$ \\
\hline
\end{tabular}

Among the 72 patients included in the study, there was an increase in retinal vascular tortuosity in $36 \%$ of cases, and this tortuosity was observed mainly in the arterial vessels (FIGURES 1 and 2).

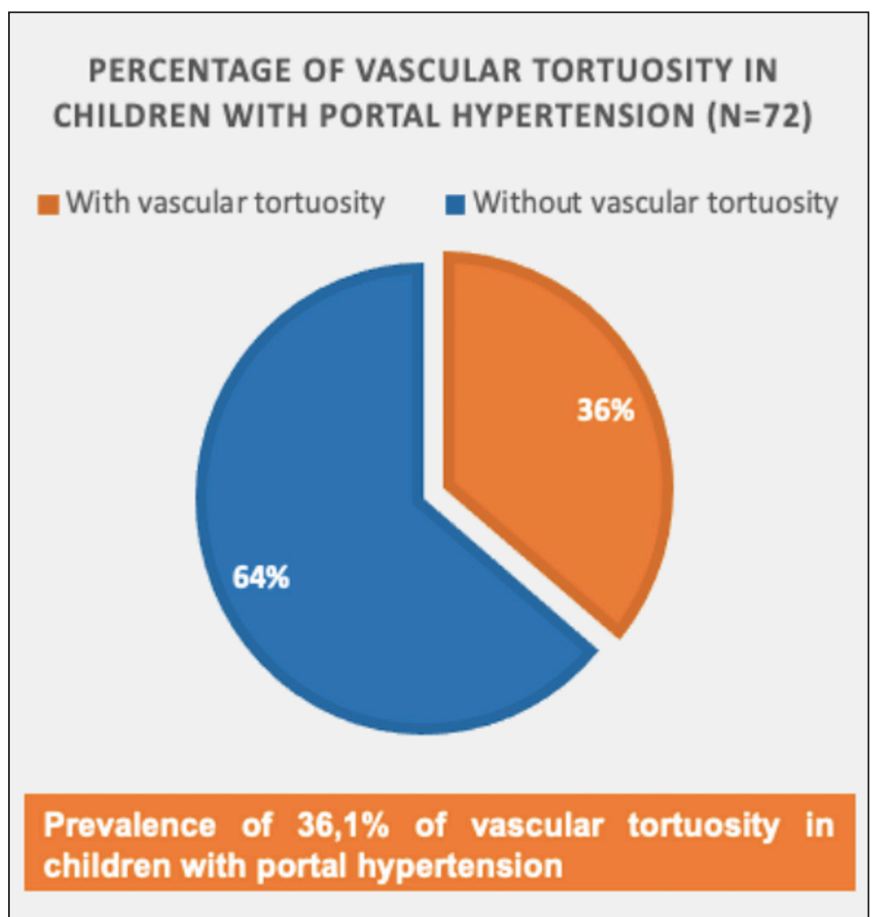

FIGURE. 1. Prevalence of retinal vascular tortuosity in children with a diagnosis of portal hypertension, being followed up at the Hepatology Department.

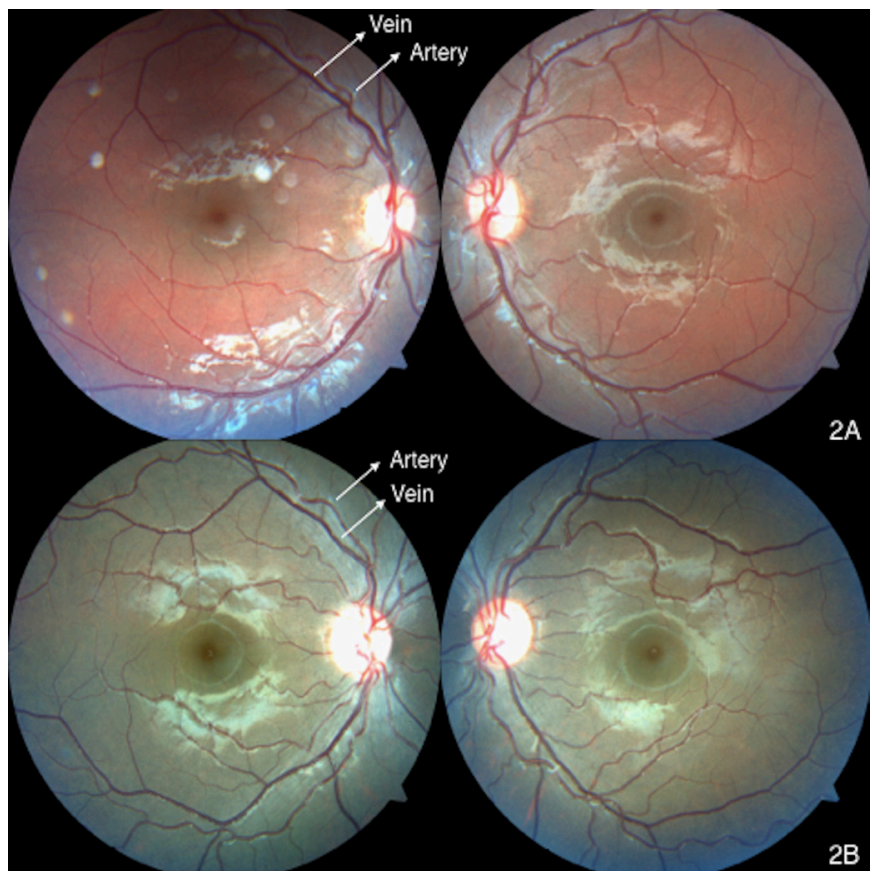

FIGURE 2. Increased retinal vascular tortuosity in patients with portal hypertension. A. A 13-year-old female patient with autoimmune hepatitis. B. Patient of 5 years, male, with liver disease. 
Based on the fundus examination, fundus photography and upper digestive endoscopy examination of the study participants, an analysis to search for an association between the presence of retinal vascular tortuosity and the presence of GEV was made. In this analysis we included 40 patients who undergone endoscopy. No association was observed between these two variables $(P=0.498)$ (FIGURE 3).

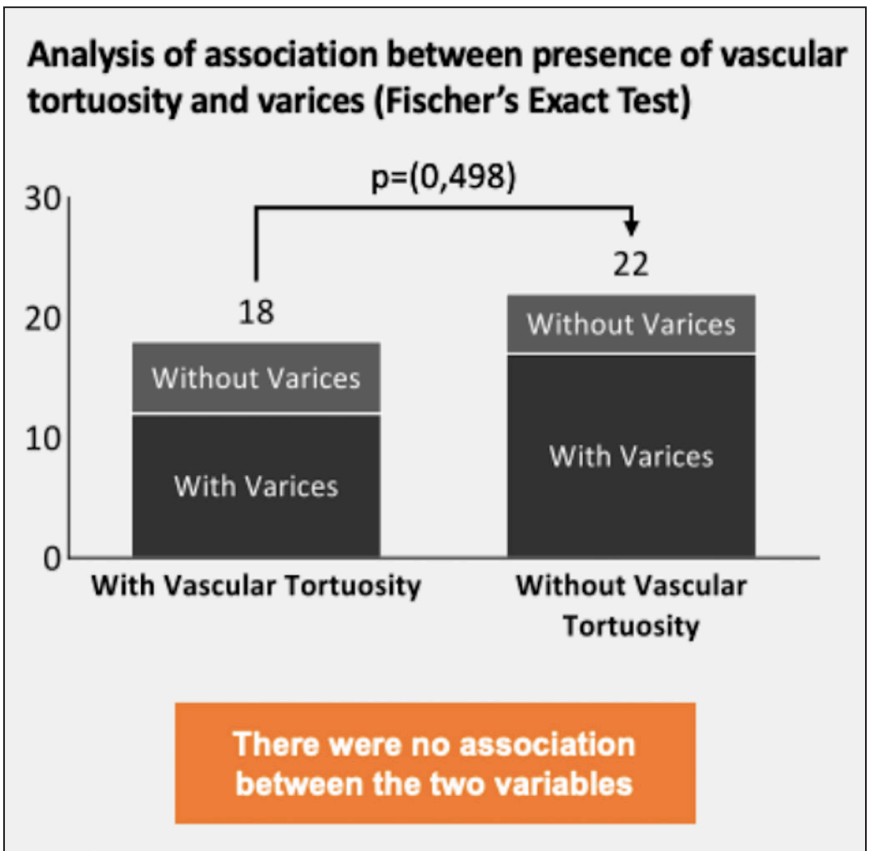

FIGURE 3. Analysis of the association between the presence of retinal vascular tortuosity in fundoscopy and gastroesophageal varices in upper digestive endoscopy.

The analysis of the association between the presence of GEV and clinical and laboratory parameters of the study participants showed that only platelet count $(P=0.001)$, bilirubin dosage $(P=0.013)$ and aspartate transaminase dosage (AST) $(P=0.042)$ were associated with the presence of gastroesophageal varices in digestive endoscopy. In this analysis we included 18 participants who had undergone endoscopy and had medical records containing all the necessary laboratory and clinical data. (TABLES 3 and 4).

\section{DISCUSSION}

There are few studies in the literature about the epidemiological characteristics of pediatric patients with PH. Our study included 72 patients under 18 years of age and diagnosed with $\mathrm{PH}$, among whom the average age was 7.1 years, with female predominance $(59.7 \%)$.

Many conditions can cause cirrhosis in children and adolescents. In the first year of life, the most frequent causes of cirrhosis are biliary atresia and genetic and metabolic diseases. On the other hand, diseases such as autoimmune hepatitis, Wilson's disease, alpha-1-antitrypsin deficiency, and primary sclerosing cholangitis account for the majority of cases in older children ${ }^{(10)}$. In this study, $35 \%$ of cases of $\mathrm{PH}$ were caused by biliary atresia. Other etiologies found were portal vein thrombosis, Alagille syndrome, familial progressive intrahepatic cholestasis, among others.
TABLE 3. Evaluation of the association between laboratory parameters and the presence of gastroesophageal varices.

\begin{tabular}{|c|c|c|c|}
\hline Variable & Without varices $(n=4)$ & With varices $(n=14)$ & $P$ \\
\hline Platelets & $179250.00 \pm 25811.82$ & $84083.33 \pm 41764.4$ & 0.001 \\
\hline $\begin{array}{l}\text { Total } \\
\text { bilirubin }\end{array}$ & $0.37 \pm 0.21$ & $5.65 \pm 6.06$ & 0.013 \\
\hline $\begin{array}{l}\text { Direct } \\
\text { bilirubin }\end{array}$ & $0.2 \pm 0.11$ & $4.48 \pm 5.14$ & 0.042 \\
\hline $\begin{array}{l}\text { Aspartate } \\
\text { transaminase }\end{array}$ & $46.75 \pm 29.74$ & $138.33 \pm 109.41$ & 0.042 \\
\hline Albumin & $4.32 \pm 0.43$ & $3.6 \pm 0.71$ & 0.103 \\
\hline PELD & $-2.5 \pm 6.35$ & $6.42 \pm 10.45$ & 0.133 \\
\hline INR & $1.16 \pm 0.32$ & $1.21 \pm 0.21$ & 0.170 \\
\hline $\begin{array}{l}\text { Alanine } \\
\text { transaminase }\end{array}$ & $47.75 \pm 40.05$ & $113.67 \pm 112.9$ & 0.212 \\
\hline Gamma GT & $143.25 \pm 180.26$ & $242.75 \pm 253.37$ & 0.521 \\
\hline Creatinine & $0.32 \pm 0.11$ & $0.36 \pm 0.12$ & 0.521 \\
\hline $\begin{array}{l}\text { Alkaline } \\
\text { phosphatase }\end{array}$ & $453.25 \pm 285.58$ & $547 \pm 326.34$ & 0.684 \\
\hline Urea & $20.5 \pm 5.45$ & $21.25 \pm 10.64$ & 0.862 \\
\hline Sodium & $138.75 \pm 1.71$ & $138.58 \pm 2.43$ & 0.862 \\
\hline
\end{tabular}

$P$ : descriptive level of the non-parametric Mann Whitney. PELD: Pediatric end-stage liver disease; INR: International normalized ratio; Gamma GT: gama-glutamiltransferase.

TABLE 4. Evaluation of the association between clinical parameters and the presence of gastroesophageal varices.

\begin{tabular}{|c|c|c|c|c|}
\hline & \multicolumn{2}{|c|}{ Varices } & \multirow{2}{*}{ Total } & \multirow{3}{*}{$P$} \\
\hline & No & Yes & & \\
\hline & $\mathbf{N}$ & $\mathbf{N}$ & $\mathbf{N}$ & \\
\hline Splenomegaly & & & & 0.250 \\
\hline No & 1 & 0 & 1 & \\
\hline Yes & 3 & 12 & 15 & \\
\hline Total & 4 & 12 & 16 & \\
\hline
\end{tabular}

Ascites

1.000

\begin{tabular}{llcc} 
No & 4 & 10 & 14 \\
Yes & 0 & 2 & 2 \\
Total & 4 & 12 & 16 \\
\hline
\end{tabular}

$P$ : descriptive level of the exact Fisher's test.

There are few studies in the literature about retinal changes associated with chronic liver disease. Abe and colleagues observed retinopathy (retinal hemorrhages and cotton wool spots) in $31.8 \%$ of patients diagnosed with chronic hepatitis $\mathrm{C}$. In the study conducted by Onder et al., 15.6\% of patients with cirrhosis (related to hepatitis B virus or alcohol consumption) presented cotton wool spots on fundoscopy ${ }^{(5)}$. Dittmer and colleagues found 11 cases of retinopathy among the 17 cirrhotic patients included in the study: five cases of cotton wool spots, two cases of intraretinal hemorrhages and one case of papilledema. These findings disappeared or significantly decreased three months after portosystemic shunts ${ }^{(11)}$. In our study, we observed an increase in retinal vascular tortuosity in $36 \%$ of children with $\mathrm{PH}$. Other changes found were intraretinal hemorrhages (one patient), disc pallor (one patient), and arteriolar narrowing (one patient). Pathophysiology involving retinopathy in cirrhosis is unknown ${ }^{(5)}$. 
Despite being the gold standard for the diagnosis of GEV in patients with $\mathrm{PH}$, upper digestive endoscopy is an invasive, costly, and time-consuming method ${ }^{(6)}$. Thus, many studies have been conducted to establish noninvasive methods capable of predicting the presence of varicose veins in patients with chronic liver disease, as well as the risk of bleeding of these vascular abnormalities. The studies carried out so far suggest that the following methods would be able to predict the presence of GEV in adult and pediatric patients: 1) Platelet count; 2) Dosage of serum albumin; 3) Presence of splenomegaly; 4) Z score of spleen size; 5) Ratio between platelet count and spleen size; 6) Ultrasonic transient elastometry (elastography) $)^{(12)}$; 7) Mathematical model: "Clinical Prediction Rule", calculated from platelet count, Z score of the spleen and albumin dosage ${ }^{(8)}$.

In this study, we evaluated the association of many clinical and laboratory methods with the presence of GEV in pediatric patients and observed that this association was present in the case of platelet count, bilirubin dosage, and aspartate transaminase dosage. Thrombocytopenia is a common complication in chronic liver disease and has been described in several studies as an isolated predictor of the presence of GEV in the pediatric population ${ }^{(8)}$. However, the cutoff point is not yet well established, ranging from 100,000 to 130,000 platelets $^{(13,14)}$. In the study conducted by Adami and colleagues, the dosage of bilirubin and dosage of aspartate transaminase was not associated with the presence of GEV. Other studies in the literature corroborate this finding ${ }^{(7)}$.

In this study, $36 \%$ of the study participants presented increased retinal vascular tortuosity. Considering the hypothesis that retinal and endoscopic vascular changes could have a similar etiopathogenesis, our research group decided to evaluate the presence of an association between these two data, since, in case of positivity, the retinal mapping could represent an essential tool for the noninvasive diagnosis of GEV. However, no statistical associations were observed between these variables.
To the best of our knowledge, this is the first study to evaluate the presence of an association between the presence of retinal vascular changes and the presence of GEV in pediatric patients with PH. Limitations of the study were the small number of participants and the subjective assessment of retinal vascular tortuosity.

\section{CONCLUSION}

In conclusion, the results of this study suggest that platelet count, bilirubin dosage, and aspartate transaminase dosage were associated with the presence of gastroesophageal varices in digestive endoscopy. Regarding the retinal findings, we found that there was an increase in retinal vascular tortuosity in $36 \%$ of pediatric patients, but no association was found with the presence of gastroesophageal varices.

\section{Authors' contribution}

Gonçalves MB: conception and design, statistical analysis, acquisition of data. Alves BQ: conception and design, acquisition of data. Marianelli BF: acquistion of data, drafting of the manuscript. Polizelli MU: analysis and interpretation of data, drafting of the manuscript. Azevedo RA, Moraes NSB: conception and design, critical revision of the manuscript. All authors have given final approval of the submitted manuscript.

\section{Orcid}

Mariana Batista Gonçalves: 0000-0003-4518-8820.

Bruno de Queiroz Alves: 0000-0001-8056-4698.

Bruna Ferraço Marianelli: 0000-0002-0141-2678.

Murilo Ubukata Polizelli: 0000-0003-2429-216X.

Ramiro Anthero de Azevedo: 0000-0002-3725-9572.

Nilva Simeren Bueno de Moraes: 0000-0001-5605-6028.

Gonçalves MB, Alves BQ, Marianelli BF, Polizelli MU, Azevedo RA, Moraes NSB. Valor de parâmetros clínicos, laboratoriais e análise da vascularização da retina em pacientes pediátricos com hipertensão portal. Arq Gastroenterol. 2020;57(2):121-5.

RESUMO - Contexto - A hipertensão portal é uma das complicações da cirrose e está associada a inúmeras manifestações sistêmicas, incluindo alterações renais, cerebrais, pulmonares, cardíacas e vasculares. Nos exames oftalmológicos de rotina realizados em nosso serviço, observamos que algumas crianças diagnosticadas com hipertensão portal apresentaram aumento da tortuosidade vascular da retina. Objetivo - 1 . Avaliar a presença de anormalidades vasculares da retina (tortuosidade vascular) em crianças diagnosticadas com hipertensão portal; 2. Investigar a associação entre tortuosidade vascular da retina e presença de varizes gastroesofágicas nessas crianças; 3. Avaliar o uso de parâmetros clínicos e laboratoriais para prever a presença de varizes gastroesofágicas em crianças com hipertensão portal. Métodos - Estudo transversal e observacional, que incluiu pacientes com idade $<18$ anos com diagnóstico de hipertensão portal. Os participantes incluídos foram submetidos ao exame de fundo de olho dilatado e fotografia de fundo com dispositivo Visucam (Carl Zeiss Meditec AG). Além disso, foram coletados dados clínicos e laboratoriais dos prontuários dos pacientes. Resultados - Um total de 72 pacientes foi incluído neste estudo e $36 \%$ deles apresentaram aumento da tortuosidade vascular da retina. Contagem de plaquetas $(P=0,001)$, dosagem de bilirrubina $(P=0,013)$ e dosagem de aspartato transaminase (AST) $(P=0,042)$ foram associados à presença de varizes gastroesofágicas na endoscopia digestiva. Não houve associação entre tortuosidade vascular da retina e presença de varizes gastroesofágicas $(P=0,498)$. Conclusão - Os resultados deste estudo sugerem que a contagem de plaquetas, a dosagem de bilirrubina e a aspartato transaminase foram associadas à presença de varizes gastroesofágicas na endoscopia digestiva. Em relação aos achados da retina, descobrimos que houve um aumento na tortuosidade vascular da retina em $36 \%$ dos pacientes pediátricos, mas nenhuma associação foi encontrada com a presença de varizes gastroesofágicas.

DESCRITORES - Hipertensão portal. Vasos retinianos. Varizes esofágicas e gástricas. Endoscopia. Doenças retinianas. 


\section{REFERENCES}

1. Hollenberg SM, Waldman B. The Circulatory System in Liver Disease. Crit Care Clin. 2016;32:331-42

2. Lagi A, La Villa G, Barletta G, Cencetti S, Bacalli S, Cipriani M, et al. Cerebral autoregulation in patients with cirrhosis and ascites. A transcranial Doppler Study. J Hepatol. 1997;27:114-20.

3. Sorrentino P, Tarantino G, Conca P, Ragucci P, Perrella A. Abnormally high resistive index of central retinal artery by ultrasound color Doppler in patients with viral chronic liver disease: Correlation with worsening liver staging. Ultrasound Med Biol. 2004;30:599-604.

4. Dillon JF, Plevris JN, Wong FC, Chan KH, Lo NT, Miller Jd et al. Middle Cerebral Artery Blood Flow velocity in patients with Cirrhosis. Eur J Gastroenterol Hepatol. 1995; 7:1087-91.

5. Onder C, Bengur T, Selcuk D. Relationship between retinopathy and cirrhosis World Journal of Gastroenterology. 2005;11:2193-6.

6. Thabut D, Moreau R, Lebrec D. Noninvasive Assessment of Portal Hypertension in Patients with Cirrhosis. Hepatology. 2011;53:683-94.

7. Adami MR, Kieling CO, Ferreira CT, Santos JL, Vieira SMG. Hipertensão portal em crianças: métodos não invasivos preditores de varizes esofágicas. Boletim Científico de Pediatria. 2014;3:79-86.
8. Adami MR, Ferreira CT, Kieling CO, Hirakata V, Vieira SMG. Noninvasive methods for prediction of esophageal varices in pediatric patients with portal hypertension. World J Gastroenterol. 2013;19:2053-9.

9. Mauro E, Gadano A. What's new in portal hypertension? Liver Int. 2020;40 (Suppl 1):122-7.

10. Pinto RB, Schneider ACR, Silveira TR. Cirrhosis in children and adolescents: An Overview. World J Hepatol. 2015;7:392-405.

11. Dittmer K, Nolte W, Tondrow M, Schwörer H. Pathologic fundus changes in advanced liver cirrhosis. Reduction of symptoms after portosystemic shunt. Ophthalmologe. 1998;95:404-7.

12. Hu Z, Li Y, Li C, Huang C, Ou Z, Guo, J, et al. Using Ultrasonic Transient Elastometry (Fibroscan) to Predict Esophageal Varices in Patients with Viral Liver Cirrhosis. Ultrasound Med Biol. 2015;41:1530-7.

13. Gana JC, Turner D, Roberts EA, Ling SC. Derivation of a clinical prediction rule for the noninvasive diagnosis of varices in children. J Pediatr Gastroenterol Nutr. 2010;50:188-93.

14. Fagundes ED, Ferreira AR, Roquete ML, Penna FJ, Goulart EMA, Filho PPF, et al. Clinical and laboratory predictors of esophageal varices in children and adolescents with portal hypertension syndrome. J Pediatr Gastroenterol Nutr. 2008;46:178-83. 